\title{
Protein and mRNA expression of gonadotropin-releasing hormone receptor in yaks during estrus
}

\author{
Sheng-dong Huo ${ }^{*}$, Tao-jie Zhang ${ }^{1}$, Ayimuguli Abudureyimu1', Jun-lin Liu', Guo-hua Zhang', \\ Zhong-ren $\mathrm{Ma}^{1,2}$
}

\footnotetext{
${ }^{1}$ Northwest Minzu University, College of Life Science and Engineering, Lanzhou, China.

${ }^{2}$ Northwest Minzu University, Animal Cell Engineering and Technology Research Center of Gansu, Lanzhou, China.
}

\begin{abstract}
To demonstrate the role of gonadotropin-releasing hormone ( $\mathrm{GnRH}$ ) in yaks (Bos grunniens), we characterized the expression of gonadotropin-releasing hormone receptor (GnRHR) mRNA and protein. The level of GnRHR mRNA in the hypothalamus was higher than that in the pineal gland, pituitary gland, and ovary during estrus. Immunofluorescence analysis showed that GnRHR was expressed in the pinealocyte, synaptic ribbon, and synaptic spherules of the pineal gland and that melatonin interacts with GnRHR via nerve fibers. In the hypothalamus, GnRHR was expressed in the magnocellular neurons and parvocellular neurons. In the pituitary gland, GnRHR was expressed in acidophilic cells and basophilic cells. In the ovary, GnRHR was present in the ovarian follicle and Leydig cells. Gonadotropin-releasing hormone receptor is located in the pineal gland, hypothalamus, pituitary, and gonad during estrus of yaks and is mainly expressed in the hypothalamus and ovaries during the estrus period.
\end{abstract}

Key Words: Bos grunniens, gonadotropin-releasing hormone receptor, immunofluorescence, real-time PCR

\section{Introduction}

Yaks are an important domesticated species that have demonstrated outstanding adaptability to the alpine climates of the Qinghai-Tibetan Plateau in China. The number of yaks in China accounts for greater than $94 \%$ of the world's total yak population (Wiener et al., 2003). They are seasonally estrous animals. Previous studies have shown that estrus can be induced in yaks (Yu et al., 1993; Yu and Chen, 2000; Huo and Long, 2014).

Gonadotropin-releasing hormone (GnRH) is a hypothalamic decapeptide that stimulates gonadotropes in the anterior pituitary gland to release gonadotropins, luteinizing hormone (LH), and follicle-stimulating hormone (FSH) by binding to the type I GnRH receptor (GnRHR), a specific G protein-coupled receptor (Sealfon et al., 1997). In the ovary, GnRH accumulates in the median eminence before ovulation. The release of GnRH is controlled by the nervous nuclei of the hypothalamus and the levels of estrogen and progesterone, which are produced by the

Received: November 15, 2016

Accepted: September 5, 2017

*Corresponding author: huoshd@xbmu.edu.cn

Copyright (C) 2018 Sociedade Brasileira de Zootecnia. This is an Open Access article distributed under the terms of the Creative Commons Attribution License (http://creativecommons.org/licenses/by/4.0/), which permits unrestricted use, distribution, and reproduction in any medium, provided the original work is properly cited. ovary. Simultaneously, GnRH and neighboring GnRH neurons stimulate the secretion of LH (Conn et al., 1995; Sealfon et al., 1997). However, the secretion of FSH is less dependent upon GnRH and is instead regulated largely by GnRH-independent factors, including gonadal activins, inhibins, and follistatins (Clarke et al., 1983, Pau et al., 1991, Kovacs et al., 1993). Gonadotropin-releasing hormone-III may act as a weak competitor for the mammalian GnRHR, which does not support the hypothesis that it selectively regulates the release of FSH in cattle (Amstalden et al., 2004). Gonadotropin-releasing hormone has been reported to selectively stimulate the release of FSH in rodents ( $\mathrm{Yu}$ et al., 1997) and in cattle during the luteal phase of the estrous cycle (Dees et al., 2001). In female yaks, GnRH is an important factor for maintaining estrus through the production of FSH and LH.

This is the first study on yaks to see the expression of GnRHR. We evaluated the expression of GnRHR in the pineal gland, hypothalamus, pituitary gland, and ovary of yaks. We also investigated the tissue-specific expression of GnRH mRNA in yaks during estrus.

\section{Material and Methods}

Six female yaks were selected for our study. When the yaks began estrus naturally, they were slaughtered, at which time tissue samples of the pineal gland, hypothalamus, 
pituitary gland, and ovary were obtained. The tissue samples were immediately stored separately in RNAlater solution (Invitrogen, Carlsbad, CA, USA) and paraformaldehyde.

Total RNA was extracted from the tissues using RNAiso Plus (Takara-Bio, Shiga, Japan) and the quality was evaluated based on the ratio of the optical densities at 260 and $280 \mathrm{~nm}$ (1.9-2.0). Reverse transcription was performed by AMV reverse transcriptase using the RNA PCR kit (Takara-Bio). First-strand cDNA synthesis was performed using $0.5 \mu \mathrm{g}$ of RNA, $5 \mathrm{mM} \mathrm{MgCl}_{2}, 1 \times \mathrm{RT}$ buffer, $1 \mu \mathrm{L}$ of dNTP mix, $10 \mathrm{U}$ of RNase inhibitor, 2.5 U of AMV-reverse transcriptase, $1.25 \mathrm{pmol}$ of oligo (dT) primer, and $3.75 \mu \mathrm{L}$ of RNase free $\mathrm{ddH}_{2} \mathrm{O}$ in a total volume of $10 \mu \mathrm{L}$ at $37{ }^{\circ} \mathrm{C}$ for $15 \mathrm{~min}$, and the reaction was terminated by heating the samples at $85^{\circ} \mathrm{C}$ for $5 \mathrm{~s}$.

To compare the expression of GnRH mRNA in the pineal gland, hypothalamus, pituitary gland, and ovary during estrus, the level of GnRH mRNA in the total RNA isolated from the various tissue samples was quantified using real-time polymerase chain reaction (PCR). The $18 \mathrm{~s}$ ribosomal RNA was used as a reference RNA for relative quantification. The primers used to amplify GnRHR cDNA were designed using the Primer Premier 6.0 program based on GnRHR mRNA sequence of Bos taurus (NCBI accession no. NM_177514). The primers used to amplify GnRH cDNA were 5'-TTCTCATCATGGTGATCTGCAA3' (forward) and 5'-GCAAATGCAACCGTCATCTTTA-3' (reverse). The primers used to amplify the cDNA of the $18 \mathrm{~s}$ ribosomal RNA were 5'-ACGGACAGGATTGACAGA3' (forward) and 5'-TCGCTCCACCAACTAAGA-3' (reverse).

Real-time PCR was performed using the Perfect Real-Time PCR kit (Takara-Bio), with $12.5 \mu \mathrm{L}$ of SXBR Premix Ex TaqTM II $(2 \times), 2.0 \mu \mathrm{L}$ of template cDNA, $1.0 \mu \mathrm{L}$ of each primer $(10 \mu \mathrm{M})$, and $4.5 \mu \mathrm{L}$ deionized $\mathrm{H}_{2} \mathrm{O}$ in a total volume of $20 \mu \mathrm{L}$. Thermal cycling was performed using an initial denaturation step at $95{ }^{\circ} \mathrm{C}$ for $2 \mathrm{~min}$, followed by 40 cycles of denaturation at $95^{\circ} \mathrm{C}$ for $10 \mathrm{~s}$ and annealment and extension at $60{ }^{\circ} \mathrm{C}$ for $30 \mathrm{~s}$. Fluorescence was measured at the end of each amplification cycle and the cycle threshold was returned to baseline during each reaction. Primer dimerization was evaluated based on the melting curve for each template. The standard curves were generated from a standard sample using a ten-fold serial dilution (from $1 \times 10^{-1}$ to $1 \times 10^{-6}$ ). The standard curve parameters were used to calculate the correlation coefficients as follows: $\mathrm{R}_{\text {GnRR }}^{2}=0.996$, with slope $=-3.531$ and the intercept $=35.821$ and $\mathrm{R}^{2}{ }_{18 \mathrm{~S}}=0.999$, with slope $=$ -3.389 and the intercept $=16.053$. Triplicate samples were used in each real-time PCR assay.
Paraffin serial sections of tissue from the cyclic group of gilts $(6 \mathrm{~mm})$ were incubated at $56{ }^{\circ} \mathrm{C}$ for $40 \mathrm{~min}$, deparaffinized in xylene, and rehydrated in a graded series of ethanol $\left(100-70 \%, \mathrm{H}_{2} \mathrm{O}\right)$ at $24.5^{\circ} \mathrm{C}$. Next, sections were denatured in citrate buffer (sodium citrate, $0.05 \%$ Tween- 20; $\mathrm{pH} 6.00$ ) at $90{ }^{\circ} \mathrm{C}$ for $40 \mathrm{~min}$ and cooled down at $24.5^{\circ} \mathrm{C}$, washed $(3 \times 10 \mathrm{~min})$ in TBS $0.2 \%$ Triton $\mathrm{X}-100$, and incubated in $10 \%$ hydrogen peroxide for $20 \mathrm{~min}$. After washing in TBS $(3 \times 10 \mathrm{~min})$, sections were incubated in $0.75 \%$ glycine for $30 \mathrm{~min}$ at $24.5^{\circ} \mathrm{C}$, washed again (TBS; $3 \times 10 \mathrm{~min}$ ), blocked in buffer for $1 \mathrm{~h}$, and then incubated overnight at $24.5^{\circ} \mathrm{C}$ with primary rabbit polyclonal antibodies (GnRHR 1:70; Santa Cruz Biotechnology). The next day, sections were washed in TBS $(3 \times 10 \mathrm{~min})$, incubated with biotinylated secondary antibody (goat anti-rabbit IgG, 1:400; Boster Bioengineering Co., Ltd., Wuhan, China) for $1 \mathrm{~h}$, and washed in TBS $(3 \times 10 \mathrm{~min})$. Next, sections were incubated with $\mathrm{ABC}$ kit solutions (Boster Bioengineering $\mathrm{Co}$ ), as described by the manufacturer, washed in TBS $(3 \times 10$ min), incubated in $\mathrm{DAB}$ (3,30-diaminobenzidine) solution (Boster Bioengineering Co), and counterstained in Mayer's hematoxylin. A negative control for the primary antibody was made using blocking peptides (Boster Bioengineering Co), whereas a secondary antibody control was performed by replacing the primary antibodies with 10\% NGS (Boster Bioengineering $\mathrm{Co}$ ).

Relative GnRHR mRNA expressions were analyzed in pineal gland, hypothalamus, pituitary gland, and ovary. The significance level was set at 0.05 . Data were expressed as mean \pm standard deviation. All statistical procedures were performed using the SPSS software, version 15.0 (IBM, Armonk, NY, USA). The following statistical model was used:

$$
\mathrm{y}_{\mathrm{ij}}=\mu+\alpha_{\mathrm{i}}+\mathrm{e}_{\mathrm{ij}} \text {, }
$$

in which $\mathrm{y}_{\mathrm{ij}}$ is the expression measured in the $j$-th animal of the $i$-th GnRHR mRNA; $\mu$ is the overall mean; $\alpha_{\mathrm{i}}$ is the effect of organ i (pineal gland, hypothalamus, pituitary gland, and ovary); and $\mathrm{e}_{\mathrm{ij}}$ is the random error associated with each observation. Significant differences were determined using protected Tukey test $(\mathrm{P} \leq 0.05)$ after the one-way ANOVA.

\section{Results}

The level of GnRHR expression in the hypothalamus was significantly higher than that in the pituitary gland, pineal gland, and ovary $(\mathrm{P}<0.01)$ (Figure 1$)$. The level of GnRHR expression in the ovary $\left(3.25795 \times 10^{-7}\right)$ was significantly higher than that in the pituitary gland $\left(8.03846 \times 10^{-9}\right)(\mathrm{P}<0.01)$. No significant difference in the 
level of GnRHR mRNA was observed between the ovary and the pineal gland.

The mammalian melatonin rhythm generating system controls the production of melatonin based on the ambient lighting conditions, with maximum melatonin levels occurring under daytime lighting conditions. The pineal gland is the main tissue where melatonin is produced. The pinealocyte, synaptic ribbon (SR), and synaptic spherules (SS) of the pineal gland expressed GnRHR protein (Figure 2). These results suggest that GnRH regulates

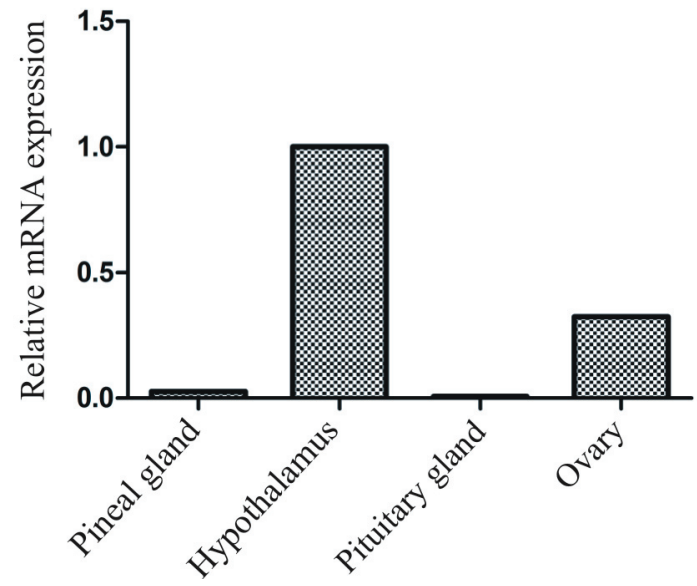

PCR - polymerase chain reaction; GnRHR - gonadotropin-releasing hormone receptor.

Values are normalized relative to the level of the 18 s ribosomal RNA.

Each sample was analyzed in triplicate.

Figure 1 - Real-time PCR analysis of GnRHR mRNA expression in the pineal gland, hypothalamus, pituitary gland, and ovary of female yaks during estrus $(n=6)$.

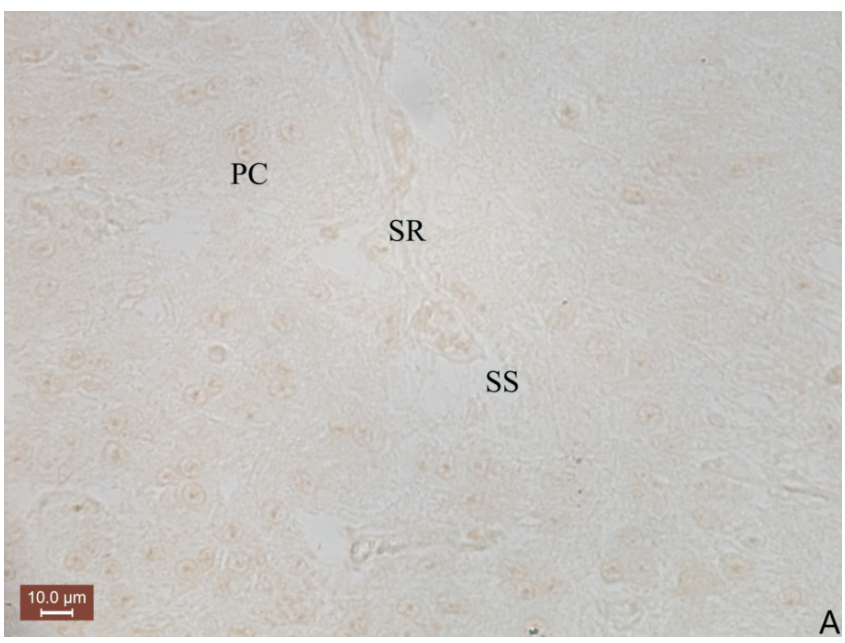

GnRHR - gonadotropin-releasing hormone receptor; GnRH - gonadotropin-releasing hormone.

The pineal gland, pinealocyte (PC), synaptic ribbon (SR), and synaptic spherules (SS) were examined for the presence of the GnRH protein.

Figure 2 - Immunofluorescence analysis of the GnRHR protein expression in the pineal gland of female yaks during estrus $(n=6)$. the secretion of melatonin from the pinealocyte, SR, and SS of the pineal gland. The immunofluorescence analysis showed that high levels of GnRHR protein were present in the magnocellular neurons (MN) and parvocellular neurons (PN) of the hypothalamus (Figure 3) and that low levels of GnRHR protein were present in $\alpha$ and $\beta$ cells of the pituitary gland (Figure 4).

In the ovary, GnRHR protein was detected in the ovarian follicle, corpus luteum, and Leydig cells. The level of GnRHR expression was highest in the follicle and lowest

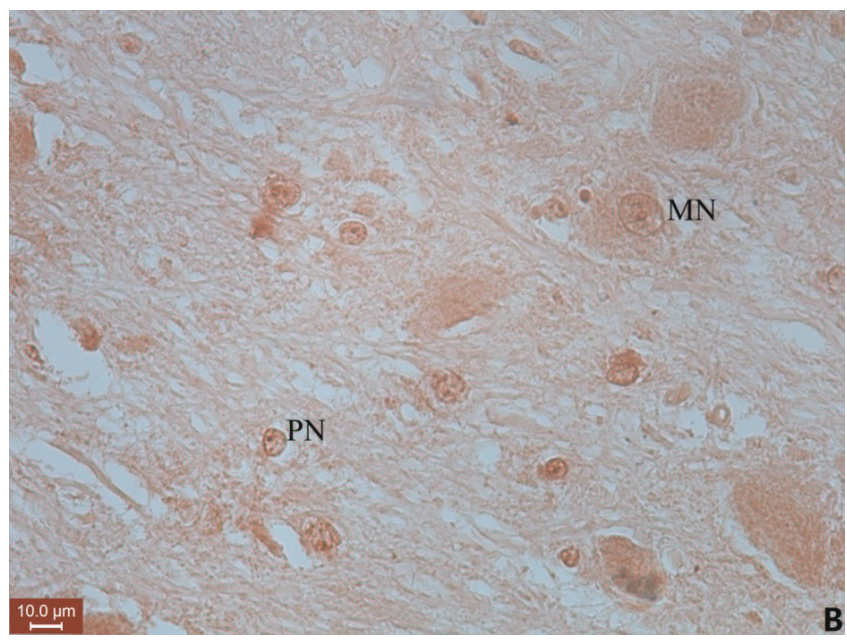

GnRHR - gonadotropin-releasing hormone receptor.

The magnocellular neurons (MN) and parvocellular neurons (PN) were examined for the presence of the GnRHR protein.

Figure 3 - Immunofluorescence analysis of GnRHR protein expression in the hypothalamus of female yaks during estrus $(n=6)$.

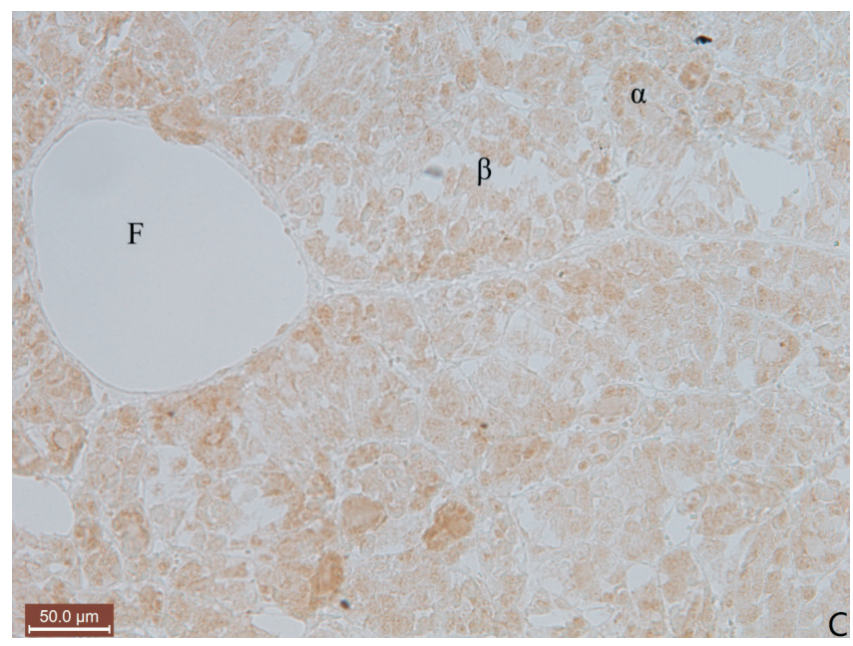

GnRHR - gonadotropin-releasing hormone receptor. Note the colloid lost in the follicles (F).

Figure 4 - Immunofluorescence analysis of GnRHR protein expression in the $\alpha$-cells $(\alpha)$ and $\beta$-cells $(\beta)$ of the pituitary gland of female yaks during estrus $(n=6)$. 
in the corpus luteum. Gonadotropin-releasing hormone receptor was also expressed in granulosa cells of the follicle during each stage of follicle development.

\section{Discussion}

In our current study, we investigated the mechanism through which $\mathrm{GnRH}$ regulates reproductive processes in female yaks in estrus. We examined the expression of GnRHR protein and mRNA in the pineal gland, hypothalamus, pituitary gland, and ovary of female yaks in estrus. Secreted by the hypothalamus, GnRH is a key factor in the regulation of mammalian reproduction. The expression of GnRHR was detected in oocytes and granular leukocytes in the ovary. These results suggest that $\mathrm{GnRH}$ is involved in the growth and maturation of ovarian follicles and oocytes and that GnRH stimulates hormone production in Leydig cells. We found that the level of GnRHR mRNA was highest in the hypothalamus and lowest in the pineal gland (Figure 1). Gonadotropin-releasing hormone receptor protein was primarily expressed in the pinealocyte (Figure 2) and the GnRHR mRNA expression was relatively low (Figure 1).

Melatonin is secreted by the pineal gland. Melatonin plays an important role in seasonal estrus in yaks (Huo and Long, 2014) and the GnRH secretion is regulated by melatonin. The expression of GnRHR mRNA and the activity of the GnRH promoter have been detected in the pineal gland as early as embryonic day (E) 13.5 (Schang et al., 2013). Melatonin inhibits the GnRH-induced secretion of LH and FSH from the anterior pituitary gland of neonatal rats, but not from that of adult rats. The effects of melatonin are mediated by specific high-affinity membrane-bound receptors that are absent in adult rats (Vanecek, 1999). The neuroendocrine effects of melatonin on reproductive physiology may be mediated by its direct effect on the GnRH neurons of the hypothalamus, through the regulation of the expression of both $\mathrm{GnRH}$ and $\mathrm{G}$ protein-coupled melatonin receptors (Roy et al., 2001).

Previous studies have found that, although the delivery of melatonin directly into the central nervous system over a period of hours do not affect either the secretion of GnRH by the hypothalamus or the secretion of LH by the pituitary gland in ewes during anestrus, it modifies the pulsatile secretion of LH in ewes deprived of the negative feedback provided by increased levels of estradiol (Romanowicz et al., 2001; Huo et al., 2015). We hypothesized that GnRH mediates melatonin secretion from the pinealocyte, SR, and SS in female yaks in estrus. We detected the expression of $\mathrm{GnRH}$ protein in the hypothalamus and the expression of GnRHR protein in MN and PN of the hypothalamus (Figure 3) and the expression of GnRHR mRNA was highest in the hypothalamus (Figure 1).

The expression of GnRH is self-regulated through paracrine and autocrine activation. Gonadotropin-releasing hormone stimulates the pituitary gland to secrete FSH and LH from $\alpha$ - and $\beta$-cells (Figure 4). In eutherians, GnRH is released in pulses from the hypothalamus and acts directly on gonadotrophic cells via the portal blood system to stimulate both the biosynthesis and secretion of $\mathrm{LH}$ and FSH. The levels of circulating gonadal steroids (Clarke et al., 1988; Gregg and Nett, 1989; Brooks et al., 1993; Sealfon et al., 1990; Yasin et al., 1995), growth factors (Gregg et al., 1991; Braden and Conn, 1992), and GnRH (Turzillo et al., 1995; Turzillo et al., 1998) during estrous modulate the sensitivity of gonadotrophic cells to GnRH by regulating the expression of GnRHR. Changes in GnRH pulse frequencies are capable of differentially regulating LH and FSH expression and secretion throughout the estrous cycle (Dalkin et al., 1989; Burger et al., 2002). Gonadotropin-releasing hormone stimulates the development of ovarian follicles in estrus (Figure 5). A previous study showed that the combination of a GnRH agonist and an antagonist completely prevented the flare-up effect of cisplatin-induced gonadotoxicity and enhanced the protective effects of cisplatin in the ovary of rats (Li et al., 2012).

Therefore, we propose a clear pathway for the effects of GnRH in reproduction. The level of GnRH produced

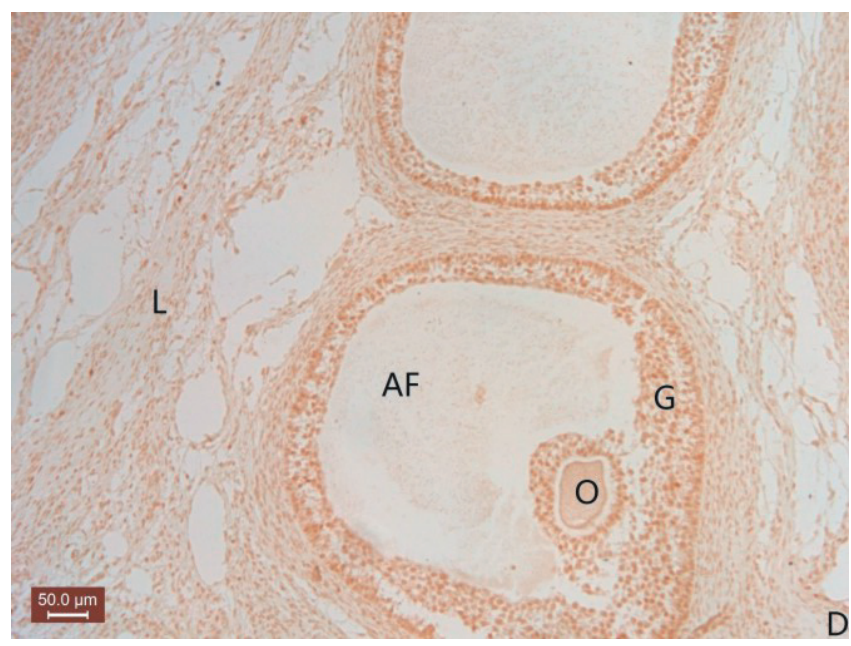

$\mathrm{AF}$ - autrum of follicle; GnRHR - gonadotropin-releasing hormone receptor.

Figure 5 - Immunofluorescence analysis of GnRHR protein expression in oocytes $(\mathrm{O})$, granulocytes $(\mathrm{G})$, and Leydig cells $(\mathrm{L})$ in the ovary of female yaks $(n=6)$ during estrus. 
in the hypothalamus is affected by seasonal estrus, which leads to the accumulation of GnRH in the hypothalamus. Gonadotropin-releasing hormone is secreted into the blood, through which it regulates hormone production by the various tissues of the pineal gland-hypothalamuspituitary gland-gonad axis and also participates in the development of the pineal gland, hypothalamus, pituitary gland, and gonads. Thus, estrous is initiated and maintained through the secretion of GnRH in yaks during the breeding season.

\section{Conclusions}

The gonadotropin-releasing hormone receptor, located in pineal gland, hypothalamus, pituitary gland, and ovary in the estrus of yaks, and gonadotropin-releasing hormone are mainly expressed in the hypothalamus and ovary by gonadotropin-releasing hormone receptor to regulate the estrous in breeding season.

\section{Acknowledgments}

This research was supported by the Fundamental Research Funds for the Central Universities (31920180007), Key research and development program of Gansu Province (17YF1NA067), and the program for CHANGJIANG Scholars and Innovative Research Team in University (IRT13091), P.R. China.

\section{References}

Amstalden, M.; Zieba, D. A.; Garcia, M. R.; Stanko, R. L.; Welsh, T. H. J.; Hansel, W. H. and Williams, G. L. 2004. Evidence that lamprey GnRH-III does not release FSH selectively in cattle. Reproduction 127:35-43.

Braden, T. D. and Conn, P. M. 1992. Activin-A stimulates the synthesis of gonadotropin-releasing hormone receptors. Endocrinology 130:2101-2105.

Brooks, J.; Taylor, P. L.; Saunders, P. T. K.; Eidne, K. A.; Struthers, W. J. and Mcneilly, A. S. 1993. Cloning and sequencing of the sheep pituitary gonadotropin-releasing hormone receptor and changes in expression of its mRNA during the estrous cycle. Molecular \& Cellular Endocrinology 94:23-27.

Burger, L. L.; Dalkin, A. C.; Aylor, K. W.; Haisenleder, D. J. and Marshall, J. C. 2002. GnRH pulse frequency modulation of gonadotropin subunit gene transcription in normal gonadotropesassessment by primary transcript assay provides evidence for roles of GnRH and follistatin. Endocrinology 143:3243-3249.

Clarke, I. J.; Cummins, J. T.; Crowder, M. E. and Nett, T. M. 1988. Pituitary receptors for gonadotropin-releasing hormone in relation to changes in pituitary and plasma gonadotropins in ovariectomized hypothalamo/pituitary-disconnected ewes. II. A marked rise in receptor number during the acute feedback effects of estradiol. Biology of Reproduction 39:349-354.
Clarke, I. J.; Cummins, J. T. and Kretser, D. M. 1983. Pituitary gland function after disconnection from direct hypothalamic influences in the sheep. Neuroendocrinology 36:376-384.

Conn, P. M.; Janovick, J. A.; Stanislaus, D.; Kuphal, D.; and Jennes, L. 1995. Molecular and cellular bases of gonadotropin-releasing hormone action in the pituitary and central nervous system. Vitamins and Hormones 50:151-214.

Dalkin, A. C.; Haisenleder, D. J.; Ortolano, G. A.; Ellis, T. R. and Marshall, J. C. 1989. The frequency of gonadotropin-releasinghormone stimulation differentially regulates gonadotropin subunit messenger ribonucleic acid expression. Endocrinology 125:917-924.

Dees, W. L.; Dearth, R. K.; Hooper, R. N.; Brinsko, S. P.; Romano, J. E.; Rahe, H.; Yu, W. H. and Mccann, S. M. 2001. Lamprey gonadotropin-releasing hormone-III selectively releases follicle stimulating hormone in the bovine. Domestic Animal Endocrinology 20:279-288.

Gregg, D. W. and Nett, T. M. 1989. Direct effects of estradiol-17 beta on the number of gonadotropin-releasing hormone receptors in the ovine pituitary. Biology of Reproduction 40:288-293.

Gregg, D. W.; Schwall, R. H. and Nett, T. M. 1991. Regulation of gonadotropin secretion and number of gonadotropin-releasing hormone receptors by inhibin, activin-A, and estradiol. Biology of Reproduction 44:725-732.

Huo, S. D. and Long, R. J. 2014. Melatonin receptor (MTNR1A and MTNR2B) expression during the breeding season in the yak (Bos grunniens). Czech Journal of Animal Science 59:140-145.

Huo, S. D.; Yuan, Q. J.; Zhang, T. J.; Liu, J. L.; Abudureyimu, A and Yang, J. T. 2015. Protein and mRNA expression of estradiol receptors during estrus in yaks (Bos grunniens). Revista Brasileira de Zootecnia 44:350-354.

Kovacs, M.; Koppan, M.; Mezo, I.; Teplan, I. and Flerko, B. 1993. Antiovulatory doses of antagonists of LH-RH inhibit LH and progesterone but not FSH and estradiol release. Journal of Neuroendocrinology 5:603-608.

Li, X.; Kang, X.; Deng, Q.; Cai, J. and Wang, Z. 2012. Combination of a GnRH agonist with an antagonist prevents flare-up effects and protects primordial ovarian follicles in the rat ovary from cisplatin-induced toxicity: a controlled experimental animal study. Reproductive Biology \& Endocrinology 11:1-8.

Pau, K. Y.; Gliessman, P. M.; Oyama, T. and Spies, H. G. 1991. Disruption of GnRH pulses by anti-GnRH serum and phentolamine obliterates pulsatile LH but not FSH secretion in ovariectomized rabbits. Neuroendocrinology 53:382-391.

Romanowicz, K.; Misztal, T.; Gajewska, A. and Barcikowski, B. 2001. Daily GnRH and LH secretion in ewes is not modified by exogenous melatonin during seasonal anestrus. Acta Neurobiologiae Experimentalis 61:289-297.

Roy, D.; Angelini, N. L.; Fujieda, H.; Brown, G. M. and Belsham, D. D. 2001. Cyclical regulation of GnRH gene expression in GT1-7 GnRHsecreting neurons by melatonin. Endocrinology 142:4711-4720.

Schang, A. L.; Bleux, C.; Chenut, M. C.; Ngo-muller, V.; Querat, B.; Jeanny, J. C.; Counis R.; Cohen-tannoudji, J. and Laverriere, J. N. 2013. Identification and analysis of two novel sites of rat GnRH receptor gene promoter activity: the pineal gland and retina. Neuroendocrinology 97:115-131.

Sealfon, S. C.; Laws, S. C.; Wu, J. C.; Gillo, B. and Miller, W. L. 1990. Hormonal regulation of gonadotropin-releasing hormone receptors and messenger RNA activity in ovine pituitary culture. Molecular Endocrinology 4:1980-1987.

Sealfon, S. C.; Weinstein, H. and Millar, R. P. 1997. Molecular mechanisms of ligand interaction with the gonadotropin-releasing hormone receptor. Endocrine Reviews 18:180-205. 
Turzillo, A. M.; Juengel, J. L. and Nett, T. M. 1995. Pulsatile gonadotropin-releasing hormone $(\mathrm{GnRH})$ increases concentrations of $\mathrm{GnRH}$ receptor messenger ribonucleic acid and numbers of $\mathrm{GnRH}$ receptors during luteolysis in the ewe. Biology of Reproduction 53:418-423.

Turzillo, A. M.; Nolan, T. E. and Nett, T. M. 1998. Regulation of gonadotropin-releasing hormone $(\mathrm{GnRH})$ receptor gene expression in sheep: interaction of GnRH and estradiol. Endocrinology 139:4890-4894.

Vanecek, J. 1999. Inhibitory effect of melatonin on GnRH-induced LH release. Reviews of Reproduction 4:67-72.

Wiener, G.; Han, J. L. and Long, R. J. 2003. The yak. 2nd ed. The Regional Office for Asia and the Pacific of the Food and Agriculture Organization of the United Nations, Bangkok.
Yasin, M.; Dalkin, A. C.; Haisenleder, D. J.; Kerrigan, J. R. and Marshall, J. C. 1995. Gonadotropin-releasing hormone (GnRH) pulse pattern regulates GnRH receptor gene expression: augmentation by estradiol. Endocrinology 136:1559-1564.

Yu, S. J. and Chen, B. X. 2000. Peripheral plasma concentrations of luteinizing hormone, oestradiol-17 $\beta$ and progesterone around oestrus in six yaks. The Veterinary Journal 160:157-161.

Yu, S. J.; Huang, Y. M. and Chen, B. X. 1993. Reproductive patterns of the yak. II. Progesterone and oestradiol-17 $\beta$ levels in plasma and milk just before the breeding season; also during normal and short oestrous cycles. British Veterinary Journal 149:585-593.

Yu, W. H.; Karanth, S.; Walczewska, A.; Sower, S. A. and McCann, S. M. 1997. A hypothalamic follicle-stimulating hormone-releasing decapeptide in the rat. Proceedings of the National Academy of Sciences of the United States of America 94:9499-9503. 